\title{
LABORATORY STUDIES OF SOME DIETS AS POLLEN SUBSTITUTES ON SOME BIOLOGICAL ACTIVITIES AND MORPHOLOGICAL MEASUREMENTS OF CAGED WORKER BEES AT DIFFERENT AGES
}

\author{
(Received:18. 2. 2008)
}

By

Azza. T. Ashour, Hoda M. Hammad, M. E. Nour and M.E. Zakaria*

Department of Economic Entomology and Pesticides, Faculty of Agriculture, Cairo University, Giza, Egypt. *Department of Apiculture, Plant Protection Research Institute, Agricultural Research Center, Dokki, Giza,Egypt.

\begin{abstract}
This work was carried out to study the effect of some diets as pollen substitutes on the biological activities and morphological measurements of caged worker bees at different ages. The obtained results indicated that the mean longest life length of caged bees ( 32 days) was recorded by the liquid yeast (diet A) (Candida tropicalis) at $25 \%$ conc. which represented $133.33 \%$ of the control (D) (24 days) fed on sugar syrup (1:1). On the other hand, the least life length (21.00 days) which represented $87.50 \%$ of the control (D) of caged bees was recorded by the diets; B (400 ml. liquid yeast $+200 \mathrm{gm}$. soya bean (lipid free $)+300 \mathrm{gm}$. bran $+100 \mathrm{gm}$. corn flour $+1000 \mathrm{gm}$. sugar $)$ and C (200 gm. dried brewer's yeast (Saccharomyces sp.) at $25 \%$ concentration $+400 \mathrm{gm}$. soya bean (lipid free) $+400 \mathrm{gm}$. barley (apical + roots) +1000 gm. sugar)._Feeding caged bees on liquid yeast (diet A) at $25 \%$ conc. resulted in the longest $\mathrm{LT}_{50 \%}$ (day) (23 days) represented $143.75 \%$ in comparison with the control (D) (16 days) fed on sugar syrup (1:1). While the diets B, C and the control (D) recorded the lowest $\mathrm{LT}_{50 \%}$ (day) (16 days for each).
\end{abstract}

Key words: biological activities,caged bees, morphological measurements, protein diets.

\section{INTRODUCTION}

In bees pollen grains are the main source of protein, lipid, minerals and vitamins. They are very important in feeding process of honey bee colonies for normal growth of bee workers and drones. (Kleinschmidt and Kondos, 1978 and Dietz, 1979). Honey bees use protein of pollen mainly to provide structural elements of muscles, glands such as; hypopharyngeal and venom glands and other tissues. Protein food is consumed when bees are forced to rear brood for long time period (Doull, 1973; Dietz; 1975 and Szymas and Pizybyl 1995). Giordani (1958) fed caged bees (hatched in an incubator) with leviathan VB (Saccharomyces yeast) and truly yeast. He found the truly yeast gave even better results than pollen. While, Haydac (1963) reported that feeding newly emerged bees on sucrose solution only caused $59 \%$ mortality during the 21 day period as compared to $12.7 \%$ in control bees fed on protein source (fresh pollen). Knox et al. (1971) in the USA compared the length of life of bees under laboratory conditions on different types of pollen and found that the average length of bees life fed on either blueberry or cranberry pollen was about two weeks longer. Hassan and Khater (2006) indicated that the length of life (full time) of caged honeybee worker was the longest (31 days) in workers fed on bee bread followed by workers fed on diet containing 2 parts corn flour +1 part defatted soybean flour (24 days) and diet containing 2 parts bean flour +1 part date paste + 1part skimmed milk (20 days), while the workers fed on diet containing 10 parts brewer's +3 parts chick pea flour +1 part skimmed milk lived for shorter period of time (19 days). Nour (1988) and Mansour (2002) studied the effect of feeding different diets on hypopharyngeal glands of caged bees.

The aim of this work was to study the effect of some protein diets as pollen substitutes on some biological and morphological measurements of caged worker bees.

\section{MATERIALS AND METHODS}

This study was carried out at the apiary yard of the Agricultural Experiment and Research Station, Faculty of Agriculture, Cairo University, Giza, during the year of 2006.

\subsection{Tested diets}

Three diets were tested as pollen substitutes as follows - Diet (A) Liquid yeast diet (Candida tropicalis) at $25 \%$ concentration. The diet contained $1000 \mathrm{gm}$. sugar $+250 \mathrm{ml}$. liquid yeast + $750 \mathrm{ml}$. water and was introduced to the caged bees in liquid form. Diet (B) was prepared as a mixture from; $400 \mathrm{ml}$. liquid yeast (Candida tropicalis $)+200$ gm. soya bean (lipid free) +300 
gm. bran + 100 gm. corn flour + 1000 gm. sugar. While, diet (C) was consisted from; $200 \mathrm{gm}$. dried brewer's yeast (Saccharomyces sp.) at $25 \%$ concentration $+400 \mathrm{gm}$. soya bean (lipid free) + $400 \mathrm{gm}$. barley (apical + roots) $+1000 \mathrm{gm}$. sugar.

Diets $\mathrm{B}$ and $\mathrm{C}$ were introduced to the tested bees in the cages in paste form, while the sugar syrup was used as control (diet D) in liquid form (1000 gm. sugar $+1000 \mathrm{ml}$ water).

Twenty five $\mathrm{ml}$. from each sugar syrup (control, diet A and D) were used in liquid form in beaker glasses and changed weekly in the caged bees during the experimental period. While $25 \mathrm{gm}$. from the diet $\mathrm{B}$ and $\mathrm{C}$ were introduced in paste form in Petri dishes and changed weekly .These diets were covered with small plastic sheet provided with holes to prevent their dryness.

\subsection{Tested worker bees}

Not less than 2600 newly emerged honeybee workers (less than $24 \mathrm{hr}$. old) were subjected to this study. The tested bees were obtained daily by placing several sealed brood combs just to emerge in the incubator at $35^{\circ} \mathrm{C}$. and $65 \% \mathrm{RH}$. for $24 \mathrm{hr}$.

\subsection{Preparing the tested cages}

Twenty four cages were used for this study. The cage diameters were $11 \mathrm{~cm}$. length, $12 \mathrm{~cm}$. width while the height was $11 \mathrm{~cm}$.. The cage was covered with wire screen provided with small holes $(2 \mathrm{~mm}$.) in three sides as well as the top side, while the bottom side of the cage was made from wood .Each cage was provided with small piece of old wax comb to encourage the bees to consume and storage the food.

\subsection{Experimental procedure}

\subsubsection{Biological measurements}

2.4.1.1.Effect of some tested diets as pollen substitutes on the life length of honeybee workers:

Not less than 1200 newly emerged honeybee workers (less than $24 \mathrm{hr}$. old) were subjected for this study. Three cages were used for each tested diet as well as another three cages for the control (fed with sugar syrup).

Hundred newly emerged honeybee workers (less than $24 \mathrm{hr}$. old) were introduced to each cage, and then the tested diets were introduced to the cages. The daily dead bees were recorded during the experimental period until all tested bees were dead in the cages for each diet.

2.4.1.2. Effect of the tested diets as pollen substitutes on some morphological measurements of honeybee workers

Not less than 2400 newly emerged honeybee workers (less than $24 \mathrm{hr}$. old) were used for this study. Three cages were used for each tested diet as well as another three cages for the control (fed with sugar syrup).
Two hundred of the newly emerged honeybee workers (less than $24 \mathrm{hr}$. old) were introduced to each cage provided with the tested diet. The following morphological measurements were recorded for the tested bees represented the following ages; newly emerged worker bees (less than 24 hr. old) , 7, 14,21 and 28 day old .

\subsubsection{Morphological measurements}

\subsubsection{Hypopharyngeal glands}

The hypopharyngeal glands of the tested honeybee workers were dissected and mounted using saline solution $(0.09 \% \mathrm{NaCl})$. According to the method of Hassanein, (1952), Wang and Moeller (1969) and Khalil, (1992), the mean length and width of the lobules ( $\mu$ / lobule) were measured and recorded.

\subsubsection{Venom acid glands and poison sac}

The tested worker bees were anaesthetized with chloroform, then the venom acid gland was dissected and mounted using Ringer's solution according to the method of Ruttner et al. (1978) . The mean length of the acid gland and poison $\mathrm{sac} / \mathrm{bee}(\mathrm{mm} / \mathrm{bee})$ for each tested bee were measured and recorded.

\subsubsection{Ventral nerve cord}

The tested bees were dissected in saline solution $(0.09 \% \mathrm{NaCl})$ to study the ventral nerve cord. The ventral nerve cord was mounted on a slide and covered by glycerin gelatin according to the method of Salama, (1987). Mean length and width of the ventral nerve ganglia as well as the length of connectives among of ganglia /bee were measured and recorded (mm/worker) (El-Sherif, 1974).

\section{RESULTS AND DISCUSSION \\ 3.1. Effect of tested diets as pollen substitutes on the length of life span of newly emerged caged honeybee workers}

The longest life span (32 days) was recorded in caged bees fed with liquid yeast (diet A) at 25\% conc. which represented $133.33 \%$ of the control (24 days) fed on sugar syrup (1:1). On the other hand, the least life length (21 days) which represented $87.50 \%$ of the control (diet D) of caged bees was recorded by the diets; $\mathrm{B}$ and $\mathrm{C}$ (Table. 1).

Concerning $\mathrm{LT}_{50 \%}$ (day) (the time at which $50 \%$ of bees were dead) it was noticed that feeding caged bees on liquid yeast diet (diet A)at $25 \%$ conc. resulted in the longest $\mathrm{LT}_{50 \%}$ (day) (23 days) which represented $143.75 \%$ in comparison with the control (16.00 days) fed on sugar syrup (1:1) (diet D). While the diets B, C and the control (diet $\mathrm{D}$ ) recorded the lowest $\mathrm{LT}_{50 \%}$ (day) (16 days for each,Table 1). 
It could be concluded that the longest life length and the longest $\mathrm{LT}_{50 \%}$ (day) of the newly emerged caged bees fed on liquid yeast diet at $25 \%$ conc. in comparison with other tested diets may be due to the highly stimulative effect of the diet components which increased the physiological status of the tested bees particularly their organs and glands. While the lowest effect of the other tested diets may be resulted from the lowest nutritive value of diets components which may be responsible for decreasing the developing of the glands and organs of the tested bees.

Table(1):The effect of some pollen substitutes on the life span (Day) of newly emerged caged worker bees

\begin{tabular}{|c|c|c|c|c|}
\hline Diet & $\mathbf{L T}_{\mathbf{5 0} \%}$ & $\begin{array}{c}\text { \%of } \\
\text { control }\end{array}$ & $\begin{array}{c}\text { Full life } \\
\text { length }\end{array}$ & $\begin{array}{c}\text { \%of } \\
\text { control }\end{array}$ \\
\hline A & $23.00 \mathrm{a}$ & 143.75 & $32.00 \mathrm{a}$ & 133.33 \\
\hline B & $16.00 \mathrm{~b}$ & 100.00 & $21.00 \mathrm{c}$ & 87.50 \\
\hline C & $16.00 \mathrm{~b}$ & 100.00 & $21.00 \mathrm{c}$ & 87.50 \\
\hline D & $16.00 \mathrm{~b}$ & 0.00 & $24.00 \mathrm{~b}$ & 0.00 \\
\hline
\end{tabular}

$\mathrm{A}=1000 \mathrm{gm}$ sugar $+250 \mathrm{ml}$. liquid yeast $+750 \mathrm{ml}$. water

$\mathrm{B}=400 \mathrm{ml}$. liquid yeast (Candida tropicalis) $+200 \mathrm{gm}$. soya bean (lipid free) $+300 \mathrm{gm}$. bran $+100 \mathrm{gm}$. corn flour $+1000 \mathrm{gm}$. Sugar.

$\mathrm{C}=200$ gm. dried brewer's yeast (Sccharomyces $\mathrm{sp})$. gm. soya bean (lipid free) $+400 \mathrm{gm}$. barley (apical + roots) +1000 gm. Sugar.

$\mathrm{D}=$ Sugar syrup as control (1:1).

$\mathrm{LT}_{50 \%}$ (day) $=$ the time at which $50 \%$ of bees were dead.

Means designated with the same letter in the same column are not significantly different at 0.05 level of probability.

The obtained results are in agreement with those of EI-Banby and Gorgui (1970), Knox et al. (1971) and Louveaxu et al. (1977). They concluded that the lifespan of worker bees increased when the rearing colonies were fed mixtures containing more supplemental protein feeding. Atallah and Abdel-Naby (1979) in Egypt fed caged groups of 100 newly emerged workers with sugar cane syrup. (B) Invert sugar (C) date extract, or (D) 1:1 sucrose solutions. After 14 days, the percentage mortalities in caged bees were $90.3 \%, 92.0 \%, 84.3 \%$ and $43.0 \%$ in A, B, C and D respectively. Mansour (2002) using some diets as pollen substitutes found that diet C ( 200 gm. dried brewer's yeast +200 gm. skim milk powder $+400 \mathrm{gm}$. soybean flour $+350 \mathrm{gm}$. clover extract +1000 gm. sugar powder ) gave good results in the first year of experimentation for the life length of caged bees, while diet A (200 gm. dried brewer's yeast $+300 \mathrm{gm}$. corn flour +400 gm. chick pea flour $+100 \mathrm{gm}$. bran $+1000 \mathrm{gm}$. sugar powder $+500 \mathrm{ml}$. water ) was the best in the second year. Hassan and Khater (2006) indicated that the length of life (full time) of caged honeybee worker was the longest (31 days) in worker fed on bee bread followed by workers fed on 2 parts corn flour +1 part defatted soybean flour (24 days) and diet; 2parts bean flour +1 part date paste +1 part skimmed milk (20 days).

3.2. Effect of tested diets as pollen substitutes on the morphological measurements of newly emerged caged worker bees (less than $24 \mathrm{hr}$. old)

\subsubsection{Hypopharyngeal glands}

There were clear significant differences in the mean length and width of hypopharyngeal lobules among the different tested caged bees which were fed different diets. Caged bees 7 and 14 days old fed with liquid yeast (diet A) at 25\% conc. recorded the highest mean length values of the lobules and followed by diet (B) and the control, while diet $(\mathrm{C})$ indicated the lowest values of mean lobules length. On the other hand the same trend was also true in the mean width values of hypopharyngeal gland lobules (Table 2). Caged bees at 21 and 28 days revealed complete reduced of hypopharyngeal glands development. Thus the lobules were not detected to measure and record their length and width.

From the obtained results it could be suggested that when the tested caged bees started to feed on the tested diets as pollen substitutes and sugar syrup as control, the lobules of hypopharyngeal glands of the tested bees showed high values in their measurements particularly at 7 and 14 day old. Increasing the measurements of the hypopharyngeal gland lobules were clearly marked with feeding bees on liquid yeast (Candida tropicalis) (diet A) at 25\% conc., followed by diet (B) and sugar syrup as control(diet D). The poorly effect of the tested diets was recorded in caged bees 21 and 28 day old where the lobules of hypopharyngeal glands were completely reduced.

\subsubsection{Venom acid gland and poison sac}

Caged bees 7 and 14 day fed with liquid yeast (diet A) at $25 \%$ conc. indicated the highest mean values of the length of acidic gland and poison sac followed by diet (B) and sugar syrup as control (diet D). While, diet (C) indicated the lowest values, particularly in the mean length of acid gland (Table 2).

Newly emerged caged bees (less than $24 \mathrm{hr}$. old) showed lower mean values of mean length of acidic gland and poison sac in comparison with caged bees at 7 and 14 days fed with liquid yeast and (diet A) at $25 \%$ conc., diet (B) and sugar syrup as control (diet D). This may be due to the fact that bees did not feed any diets in the cages at zero days. 
Table (2): The effect of some pollen substitutes on some morphological measurements of the hypopharyngeal glands, venom acid gland and poison sac of caged honeybee workers at different ages.

\begin{tabular}{|c|c|c|c|c|c|}
\hline \multirow[b]{2}{*}{ Age of bees } & \multirow{2}{*}{$\begin{array}{c}\text { Tested } \\
\text { diets }\end{array}$} & \multicolumn{2}{|c|}{ Hypopharyngeal glands } & \multirow{2}{*}{$\begin{array}{l}\text { Mean length of } \\
\text { acid gland (mm.) }\end{array}$} & \multirow{2}{*}{$\begin{array}{c}\text { Mean length of } \\
\text { poison sac }(\mathrm{mm} .)\end{array}$} \\
\hline & & $\begin{array}{l}\text { Mean length of } \\
\text { lobules }(\boldsymbol{\mu})\end{array}$ & $\begin{array}{l}\text { Mean width of } \\
\text { lobules }(\boldsymbol{\mu})\end{array}$ & & \\
\hline $\begin{array}{c}\text { Newly emerged } \\
\text { bees }\end{array}$ & & $11.56 \mathrm{~g}(6.25-18.75)$ & $7.81 \mathrm{~h}(6.25-12.5)$ & 12.45 e $(9.70-17.00)$ & 1.33 f (1.00-1.75) \\
\hline \multirow{4}{*}{7 days } & $\mathbf{A}$ & 20.83 a $(15.63-28.13)$ & 10.63 e $(12.50-15.63)$ & $14.00 \mathbf{c}(8.50-17.50)$ & $1.63 \mathrm{~d}(1.25-2.00)$ \\
\hline & B & 18.64 c $(12.50-28.13)$ & 10.53 e $(12.50-15.63)$ & $13.10 \mathrm{~d}(9.00-16.20)$ & $1.58 \mathrm{~d}(1.10-1.80)$ \\
\hline & $\mathbf{C}$ & 15.63 e $(9.38-21.88)$ & $9.79 \mathrm{~d}(6.25-15.63)$ & $11.54 \mathrm{f}(9.00-14.50)$ & 1.85 b (1.50- 2.15$)$ \\
\hline & D & 18.75 c $(12.50-28.13)$ & $11.04 \mathrm{~b}(6.25-15.63)$ & 12.74 e $(9.50-18.50)$ & $1.59 \mathrm{~d}(1.25-2.00)$ \\
\hline \multirow{4}{*}{14 days } & $\mathbf{A}$ & 19.98 b (15.63-28.13) & 13.39 a $(9.38-18.75)$ & $15.30 \mathrm{a}(11.00-27.00)$ & $2.09 \mathrm{a}(1.75-2.30)$ \\
\hline & B & $17.99 \mathrm{~d}(15.63-25.00)$ & $8.52 \mathrm{f}(6.25-15.63)$ & $14.66 \mathrm{~b}(12.00-18.00)$ & 1.44 e $(1.25-1.60)$ \\
\hline & $\mathbf{C}$ & $14.10 \mathrm{f}(14.0-20.25)$ & $8.10 \mathrm{~g}(6.0-14.90)$ & $10.80 \mathrm{~g}(8.10-14.70)$ & $1.78 \mathrm{c}(1.15-1.95)$ \\
\hline & D & 15.31 e $(9.38-21.88)$ & 10.42 c $(6.25-15.63)$ & $10.50 \mathrm{~h}(8.50-11.50)$ & $1.87 \mathrm{~b}(1.50-2.25)$ \\
\hline \multirow{4}{*}{21 days } & $\mathbf{A}$ & 0.00 & 0.00 & 8.88 j (5.00-13.00) & $1.28 \mathrm{~g}(1.00-1.60)$ \\
\hline & B & 0.00 & 0.00 & 0.00 & 0.00 \\
\hline & $\mathbf{C}$ & 0.00 & 0.00 & 0.00 & 0.00 \\
\hline & D & 0.00 & 0.00 & 14.00 c $(12.00-16.00)$ & $1.57 \mathrm{~d}(1.50-2.00)$ \\
\hline \multirow{4}{*}{28 days } & $\mathbf{A}$ & 0.00 & 0.00 & $9.67 \mathrm{i}(8.00-11.50)$ & $1.37 \mathrm{f}(1.25-1.50)$ \\
\hline & B & 0.00 & 0.00 & 0.00 & 0.00 \\
\hline & $\mathbf{C}$ & 0.00 & 0.00 & 0.00 & 0.00 \\
\hline & D & 0.00 & 0.00 & 0.00 & 0.00 \\
\hline
\end{tabular}

$\mathrm{A}=1000 \mathrm{gm}$ sugar $+250 \mathrm{ml}$. liquid yeast (Candida tropicalis $)+750 \mathrm{ml}$. water

$\mathrm{B}=400 \mathrm{ml}$. liquid yeast (Candida tropicalis) $+200 \mathrm{gm}$. soya bean (lipid free) $+300 \mathrm{gm}$. bran $+100 \mathrm{gm}$. corn flour $+1000 \mathrm{gm}$. Sugar.

$\mathrm{C}=200 \mathrm{gm}$. dried brewer's yeast (Sccharomyces sp.) + $400 \mathrm{gm}$. soya bean (lipid free) + $400 \mathrm{gm}$. barley (apical + roots) $+1000 \mathrm{gm}$. Sugar.

$\mathrm{D}=$ Sugar syrup as control $(1: 1)$.

Means designated with the same letter in the same column are not significantly different at 0.05 level of probability. 
Laboratory studies of some diets as pollen.

Table (3): The effect of some pollen substitutes on some morphological measurements of the ventral nerve cord of caged honeybee workers at different ages.

\begin{tabular}{|c|c|c|c|c|c|c|c|c|c|c|c|c|c|c|c|}
\hline \multirow{3}{*}{$\begin{array}{l}\text { Age of } \\
\text { bees }\end{array}$} & \multirow{3}{*}{$\begin{array}{c}\text { Tested } \\
\text { diets }\end{array}$} & \multicolumn{10}{|c|}{ Ganglia } & \multirow{2}{*}{\multicolumn{4}{|c|}{$\begin{array}{c}\text { Connectives } \\
\text { Mean length }(\mathrm{mm} .)\end{array}$}} \\
\hline & & \multicolumn{5}{|c|}{ Mean length (mm.) } & \multicolumn{5}{|c|}{ Mean width (mm.) } & & & & \\
\hline & & 1 & 2 & 3 & 4 & 5 & 1 & 2 & 3 & 4 & 5 & 1 & 2 & 3 & 4 \\
\hline $\begin{array}{c}\text { Newly } \\
\text { emerged } \\
\text { bees }\end{array}$ & & $19.78 \mathrm{~h}$ & $20.31 \mathrm{f}$ & $20.31 \mathrm{f}$ & $26.25 \mathrm{~g}$ & $19.38 \mathrm{~g}$ & $16.66 \mathrm{~h}$ & $20.31 \mathrm{f}$ & $18.13 \mathrm{~g}$ & $23.75 \mathrm{e}$ & $19.38 \mathrm{e}$ & $78.13 \mathrm{i}$ & $61.25 \mathrm{k}$ & $63.13 \mathrm{~h}$ & $11.25 \mathrm{e}$ \\
\hline \multirow{4}{*}{7 days } & $\mathbf{A}$ & $28.13 a$ & $19.38 \mathrm{~g}$ & $18.13 \mathrm{~h}$ & $23.75 \mathrm{~h}$ & $23.44 c$ & $20.94 d$ & $20.63 \mathrm{e}$ & $21.88 b$ & $21.25 \mathrm{f}$ & $18.75 \mathrm{f}$ & $82.28 \mathrm{~h}$ & $70.63 \mathrm{~h}$ & $66.25 \mathrm{e}$ & $10.94 \mathrm{~F}$ \\
\hline & B & 0.00 & $24.06 \mathrm{~b}$ & $18.75 \mathrm{~g}$ & $23.44 \mathrm{I}$ & $22.81 \mathrm{~d}$ & 0.00 & $19.69 \mathrm{~g}$ & $21.09 \mathrm{f}$ & $19.53 \mathrm{~g}$ & $21.88 \mathrm{~b}$ & $93.75 \mathrm{~d}$ & $67.81 \mathrm{i}$ & $65.63 \mathrm{f}$ & $7.81 \mathrm{~h}$ \\
\hline & $\mathbf{C}$ & $24.06 \mathrm{c}$ & $21.88 \mathrm{~d}$ & $21.88 \mathrm{~b}$ & $31.25 \mathrm{~b}$ & $21.88 \mathrm{e}$ & $20.94 \mathrm{~d}$ & $19.53 \mathrm{~g}$ & $18.75 \mathrm{f}$ & $27.34 \mathrm{a}$ & $25.00 \mathrm{a}$ & $75.94 \mathrm{~g}$ & $66.25 \mathrm{j}$ & $62.50 \mathrm{i}$ & $10.31 \mathrm{~g}$ \\
\hline & D & $23.44 \mathrm{~d}$ & $26.56 \mathrm{a}$ & $23.44 a$ & $34.38 \mathrm{a}$ & $16.41 \mathrm{~h}$ & $17.19 \mathrm{~g}$ & $24.22 \mathrm{a}$ & $20.31 \mathrm{~d}$ & $19.53 \mathrm{~g}$ & $17.19 \mathrm{~h}$ & $84.38 \mathrm{~g}$ & $73.44 \mathrm{f}$ & $70.31 \mathrm{c}$ & $10.16 \mathrm{~g}$ \\
\hline \multirow{4}{*}{14 days } & A & $17.97 \mathrm{i}$ & $19.53 \mathrm{~g}$ & $17.19 \mathrm{i}$ & $30.47 \mathrm{c}$ & $25.00 \mathrm{a}$ & $17.97 \mathrm{f}$ & $17.97 \mathrm{~h}$ & $17.97 \mathrm{~g}$ & $25.78 \mathrm{~b}$ & $25.00 \mathrm{a}$ & $89.84 \mathrm{e}$ & $72.66 \mathrm{~g}$ & $64.84 \mathrm{~g}$ & $10.94 \mathrm{f}$ \\
\hline & B & $25.00 \mathrm{~b}$ & $23.13 \mathrm{c}$ & $20.63 \mathrm{e}$ & $27.50 \mathrm{f}$ & $24.38 \mathrm{~b}$ & $22.81 \mathrm{~b}$ & $21.88 \mathrm{~b}$ & $21.88 \mathrm{~b}$ & $18.75 \mathrm{~h}$ & $21.25 \mathrm{c}$ & $87.5 \mathrm{f}$ & $75.00 \mathrm{~d}$ & $68.75 \mathrm{~d}$ & $12.5 \mathrm{~d}$ \\
\hline & $\mathbf{C}$ & 0.00 & 0.00 & 0.00 & 0.00 & 0.00 & 0.00 & 0.00 & 0.00 & 0.00 & 0.00 & 0.00 & 0.00 & 0.00 & 0.00 \\
\hline & D & $21.09 \mathrm{f}$ & $21.25 \mathrm{e}$ & $21.25 \mathrm{c}$ & $28.13 \mathrm{e}$ & $22.81 \mathrm{~d}$ & $25.00 \mathrm{a}$ & $21.25 \mathrm{c}$ & $23.75 \mathrm{a}$ & $24.22 \mathrm{~d}$ & $21.88 \mathrm{~b}$ & $96.88 \mathrm{c}$ & $74.38 \mathrm{e}$ & $66.25 \mathrm{e}$ & $10.31 \mathrm{~g}$ \\
\hline \multirow{4}{*}{21 days } & A & $21.88 \mathrm{e}$ & $20.94 \mathrm{e}$ & $20.94 \mathrm{~d}$ & $28.13 \mathrm{e}$ & $21.88 \mathrm{e}$ & $21.88 \mathrm{c}$ & $17.81 \mathrm{~h}$ & $18.75 \mathrm{f}$ & $25.00 \mathrm{c}$ & $20.31 \mathrm{~d}$ & $115.63 \mathrm{a}$ & $82.19 \mathrm{~b}$ & $77.19 \mathrm{a}$ & $17.19 \mathrm{a}$ \\
\hline & B & 0.00 & 0.00 & 0.00 & 0.00 & 0.00 & 0.00 & 0.00 & 0.00 & 0.00 & 0.00 & 0.00 & 0.00 & 0.00 & 0.00 \\
\hline & $\mathbf{C}$ & 0.00 & 0.00 & 0.00 & 0.00 & 0.00 & 0.00 & 0.00 & 0.00 & 0.00 & 0.00 & 0.00 & 0.00 & 0.00 & 0.00 \\
\hline & D & $21.88 \mathrm{e}$ & $17.19 \mathrm{~h}$ & $21.88 \mathrm{~b}$ & $29.69 \mathrm{~d}$ & $21.88 \mathrm{e}$ & $18.75 \mathrm{e}$ & $20.31 \mathrm{f}$ & $19.53 \mathrm{e}$ & $25.78 \mathrm{~b}$ & $21.09 \mathrm{c}$ & $96.88 \mathrm{c}$ & $81.25 \mathrm{c}$ & $75.78 \mathrm{~b}$ & $13.28 \mathrm{c}$ \\
\hline \multirow{4}{*}{28 days } & A & $20.94 \mathrm{~g}$ & $20.94 \mathrm{e}$ & $21.88 \mathrm{~b}$ & $30.31 \mathrm{c}$ & $20.94 \mathrm{f}$ & $21.88 \mathrm{c}$ & $20.94 \mathrm{~d}$ & $19.69 \mathrm{e}$ & $25.94 \mathrm{~b}$ & $17.81 \mathrm{~g}$ & $112.5 \mathrm{~b}$ & $83.44 \mathrm{a}$ & $77.19 \mathrm{a}$ & $16.56 \mathrm{~b}$ \\
\hline & B & 0.00 & 0.00 & 0.00 & 0.00 & 0.00 & 0.00 & 0.00 & 0.00 & 0.00 & 0.00 & 0.00 & 0.00 & 0.00 & 0.00 \\
\hline & C & 0.00 & 0.00 & 0.00 & 0.00 & 0.00 & 0.00 & 0.00 & 0.00 & 0.00 & 0.00 & 0.00 & 0.00 & 0.00 & 0.00 \\
\hline & D & 0.00 & 0.00 & 0.00 & 0.00 & 0.00 & 0.00 & 0.00 & 0.00 & 0.00 & 0.00 & 0.00 & 0.00 & 0.00 & 0.00 \\
\hline
\end{tabular}

$\mathrm{A}=1000 \mathrm{gm}$ sugar $+250 \mathrm{ml}$. liquid yeast $+750 \mathrm{ml}$. water

$\mathrm{B}=400 \mathrm{ml}$. liquid yeast (Candida tropicalis) $+200 \mathrm{gm}$. soya bean (lipid free $)+300 \mathrm{gm}$. bran $+100 \mathrm{gm}$. corn flour $+1000 \mathrm{gm}$. Sugar.

$\mathrm{C}=200 \mathrm{gm}$. dried brewer's yeast (Sccharomyces sp.) $+400 \mathrm{gm}$. soya bean (lipid free $)+400 \mathrm{gm}$. barley (apical + roots $)+1000 \mathrm{gm}$. Sugar

$\mathrm{D}=$ Sugar syrup as control $(1: 1)$.

Means designated with the same letter in the same column are not significantly different at 0.05 level of probability. 
Caged bees 21 and 28 day old recorded the lowest mean values in the mean length of acidic gland and poison sac in comparison with the tested bees 7 and 14 day old.

From the obtained results it could be concluded that caged bees fed with liquid yeast (diet A) at $25 \%$ conc. followed by diet (B) and sugar syrup as the control (diet D), indicated the lower mean values. While the tested bees at 21 and 28 day indicated the lowest mean values of mean length of acidic gland and poison sac than bees 7 and 14 day old. It could be suggested that the appearance of ovaries development in the tested caged bees particularly 14, 21 and 28 days old, sharply affected the reducing development of the length of acidic gland and poison sac. This may be due to the unavailable protein components which are needed to venom acid gland and poison sac development. Most of this protein may be used by the bees for developing the ovaries in the caged bees.

\subsubsection{Ventral nerve cord}

There were clear significant differences in the mean length and width of the ganglia of the caged bees represented different ages fed with different pollen substitutes as well as sugar syrup as the control (Table 3 ). The newly emerged caged bees (less than $24 \mathrm{hr}$. old) indicated the lowest value of the mean length and width of the ganglia. The measurements were clearly increased with increasing the age of tested caged bees. Caged bees fed with diets (B and C) as well as sugar syrup (diet D), recorded the highest values of the mean length and width of the ganglia. While the tested bees fed with liquid yeast (Candida tropicalis) (diet A) at $25 \%$ conc. showed the lowest values, particularly in caged bees 7 and 14 day old. In general the measurements of the ganglia (length and width) were clearly decreased particularly in caged bees 14, 21 and 28 day old.

Concerning the mean length values of the connectives, liquid yeast (diet A) at $25 \%$ conc. and diet (B) indicated the highest values among the tested diets of caged bees represented 7 and 14 days old. Whereas, caged bees 21 and 28 day old indicated the highest values in caged bees fed with liquid yeast (diet A) at $25 \%$ conc. than the control one (diet D).

From the obtained results it could be suggested that the newly emerged caged bees which were not fed any diet in the cages at zero days recorded the lowest mean values of length and width of ganglia and their connectives. When these bees were fed with the pollen substitutes as well as sugar syrup as control, the measurements of the ganglia and connectives were clearly increased particularly in caged bees 7 day old fed with diets (B and $\mathrm{C}$ ) as well as the control one (diet D). When tested caged bees increased in the age; 14, 21 and 28 day old the measurements of the ganglia clearly decreased in all treatments. While, the measurements of the connectives were markedly increased particularly in caged bees fed with liquid yeast (Candida tropicalis) $(\operatorname{diet} \mathrm{A})$ at $25 \%$ conc. This may be due to the lower amounts of protein which were available for developing the ganglia and its connectives. It could be concluded that the ovaries development of caged bees particularly in ages 14, 21 and 28 days consumed high amounts of protein components for reactivate the ovary development.

The obtained results are in agreement with the following authors; Whal (1954), Standifer et al. (1960) and Dietz (1969). They found that the development of body tissues, muscles, and glands such as the hypopharyngeal glands depends upon adequate amounts of some pollen substitutes in the honey bees diet. Rosca et al. (1972) in Poland fed groups of 100 bees with 50\% sugar syrup alone (control) or with dried milk (5\%) or brewer's yeast (2\%). They found that the mean length of acinus of hypopharyngeal glands was $125_{\mathrm{u}} \mathrm{m}$ for control, $144{ }_{\mathrm{u}} \mathrm{m}$ for those given milk and $131_{\mathrm{u}} \mathrm{m}$ for those fed on yeast. El-Barbary (1980) in Egypt found that the degree of development of hypopharyngeal gland and fat body was nearly about equal in workers fed fresh or stored bee collected pollen soybean meal and brewer's dried yeast at any level of concentration. Szymas (1994) in Poland mentioned that six pollen substitutes, with an amino acid composition similar to that of pollen were fed to groups of test bees in the laboratory. Bees fed on all diets showed satisfactory development of hypopharyngeal glands. Mansour (2002) found that the interaction between the diet of $200 \mathrm{gm}$. Dried brewer's yeast $+200 \mathrm{gm}$. Skim milk powder $+400 \mathrm{gm}$. Soybean flour $+350 \mathrm{gm}$. Clover extract $+1000 \mathrm{gm}$. Sugar powder and 12 day old was the best on the development of the hypopharyngeal glands. while the interaction among the diet of $200 \mathrm{gm}$. Dried brewer's yeast + $200 \mathrm{gm}$. Skim milk powder $+400 \mathrm{gm}$. Soybean flour $+350 \mathrm{gm}$. Clover extract $+1000 \mathrm{gm}$. Sugar powder and 18 days old was the best. Hassan and Khater (2006) noticed that, the maximum development of hypopharyngeal glands was achieved between $6-12$ days for all diets used as pollen substitutes. On the other hand, Youssef (1964) reported that in the 5 day pupae of honey bee worker, the total length of the ventral nerve cord increased and the sixth and seventh abdominal ganglia became joined together. AboEl-Naga, (1965) found that the terminal ganglion in the mature larval of the worker bee is in fact a 
fusion of at least three ganglia. No external changes was observed in the central nervous system during the first day of the prepupal stage. In addition on the second day the longitudinal connectives between the first and second ganglia elongated. The second and third thoracic ganglia became united with the first two abdominal ganglia to form a large one. The longitudinal connectives between the third, fourth and fifth abdominal ganglia elongated. On the third day the suboesophageal ganglion became much smaller, while the second compound ganglion grew bigger. El-Sherif (1974) in his comparative histomorphological studies on the different individuals of honey bees found that the morphological differences in the nervous system were slightly affected with the age of pupa and adults. In fifth day pupa of worker $6^{\text {th }}$ abdominal ganglion joined with $7^{\text {th }}$ one. Symmetrical number of lateral nerves of ganglia during post- embryonic development of drone was observed. The reverse was shown in the worker, an asymmetrical number of lateral nerves of 8 abdominal ganglions slightly appeared in the second day prepupae, and then clearly observed during pupal and adult stages. Four nerves arised from the right side of the terminal ganglion and three from left side of the same ganglion.

\section{REFERENCE}

Abo-El-Naga A.M. (1965). Studies on the Anatomy and Histology of the Mature Larvae of the Queen, Worker and Drone of Apis mellifera L. (Ph.D., Thesis. Fac. Agric, Alex. Univ. Egypt, 180pp).

Atallah M. A. and Abdel-Naby A. A. (1979). The Effect of Feeding Honeybees With Brown and Unrefined Sugar on the Rectal Contents and Mortality Rate. (Proc XXVII Inter. Congr. Apic. Athens, Apimondia Publ. House: 221225).

Dietz A. (1969). Initiation of pollen consumption and Pollen Movement Through the Alimentary Canal of Newly Emerged Honey Bees. (ann. Entomol. Soc. Amer., 62: 43-46).

Dietz A. (1975). Nutrition of Honey Bee. In "The Hive and the Honey Bee". (Dadant and Sons, Inc. Hamilton, 111, pp. 125-156).

Dietz A. (1979). Nutrition of the Adult Honeybee; (From the Hive and The Honeybee. Pp. 125156. Hamilton, III Dadant \& Sons Inc).

Doull K. M. (1973). Relationships between pollen, brood rearing and consumption of pollen supplement by honeybees. Apidologie, 4 (4): 285-293.

El-Sherif M. E. (1974). Compartive histomorpholgical studies on the different individuals of the honeybee Colony. (M.sc.
Thesis, Fac. Science, Ain Shams Univ., Egypt).

EL-Banby M. A. and Gorgui W. A (1970). Development of Trance Bees Whose Colonies Fed on Sugar Syrup and Different Kinds of Pollen Substitutes. (Res. Bull; Fac. Agric; Ain Shams Univ., 616: 22 pp).

El-Barbary N. S. S. (1980). Effect of Different Pollengrains and Pollen Substitutes on the Development of Certain External and Internal Features of the Honeybee. (Ph. D. Thesis, Fac. Agric. Alexandria Univ., Egypt, 190 pp).

Giordani G. (1958). Yeast in Feeding of Honeybees. (Bee World, 39 (3): 243 - 250).

Hassan R.E. and Khater A.M. (2006). Influence of Pollen Substitutes on Longevity and Hypopharyngeal Glands of Caged Honey Bee Workers (Apis Mellifera L.). (j. Agric. Sci. Mansoura Univ., 31 (1): 419-427).

Hassanein M. H. (1952). The Effect of Infection With Nosema Apis on the Hypopharyngeal Salivary Glands of the Workers Honeybees.( Proc. R. Ent. London, 27: 22-27).

Haydac M. H. (1963). Influence of Storage in the Nutritive Value of Pollen in Brood Rearing Honeybee.(J. Apic. Res., 2 (2): 105-107).

Khalil Y. S. I. (1992). Effect of Varroa Infestation on the Mortality Rate, Body Weight and Development of Hypopharyngeal Glands of Honeybee Workers. (Zagazig, j. Agric. Res., 19 (2): 901-908).

Kleinschmidt G. J. and Kondos A. C. (1978). The Effect of Dietary Protein on Colony Performance. (Australas. Beekpr., 79 (12): 251-257).

Knox D. A., Shimanuki H. and Herbert E. W. (1971). Diet and the Longevity of Adult Honeybees. (.J. Econ. Ent. 64 (6): 1415-1416).

Louveaux J. , Moussy G. and Pouvreu A. (1977). New Solutions to Problems of Nutrition of Honeybees. (Proc. Xxvi th Inter. Apic. Congr, Abelaide, 367-370).

Mansour A.M.S. (2002). The Effect of Artificial Feeding on Some Activities of Honey Bees. (M.Sc. Thesis, Fac. Agric. Mansoura Univ., 104pp).

Nour M.E. (1988). Some Factors Affecting Quality of Egyptian Honey. (Ph.D. Thesis, Fac. Agric., Cairo Univ., Egypt).

Rosca O., Rusu C. and Frasinel C. (1972). Effect of Protein Supplements on the Development and Secretory Activity of the Pharyngeal Glands in Honeybees. (Lucrari Stintifica Institutul Agronomic (Ion Lonescu de ia Brad). Iasii, 1193-1198).

Ruttner F., Tassen I. and Louveaux J. (1978). Biometrical Statistical Analysis of the 
Geographic Variability of Apis mellifera L. (Apidologie, 9 (4): 363-381).

Salama R.A.A. (1987).Comparative Neuronatomy of the Termites of Reticulitermes santonensis (Feyt.) (Rhinotermitdae) and Amitermes oesertrum (Desen.) (Termitidae). Ph. D. Thesis, Fac. Agric., Cairo Univ., Egypt.

Standifer I. N., Todd F. E. and Kemmerer A. R. (1960). Relative Availabhity Levels of Various Protein to Honeybee. (Ann. Ent. Soc. Amer., 53: 618-825).

Szymas B. (1994). Evaluation of the Nutritive Value of Pollen Substitutes for honeybees (Apis mellifera L). (Roczniki Akademii Rolniczej Poznaniu Rozprawy Naukowe, 256-268).
Szymas B. and Pizybyl A. (1995). Application of Potato Protein in the Feeding of Honeybees (Apis mnellifera L.). (Pszczelnicze-ZeszytyNaukowe, 39 (1): 49-53; (c. F. Cab Abst).

Wang D. I. and Moeller F. E.(1969). Histological Comparisons of the Development of Hypopharyngeal Glands in Healthy and Nosema Infected Worker Honeybees. (J. Invert. Path., 14 (2): 135-142).

Whal O. (1954). Experiments on the Nutritional Value of Pollen Substitute for Honeybee. (Insects Sociaux, 1 (3): 285-292).

Youssef N.N. (1964). Topograph of the Abdominal Nervous System and A Reveiw of the Abdominal Musculature of the Honey Bee Apis mellifera L. M. Sc. Thesis, Uthah State Univ. Library Logan, Utah. 190 PP

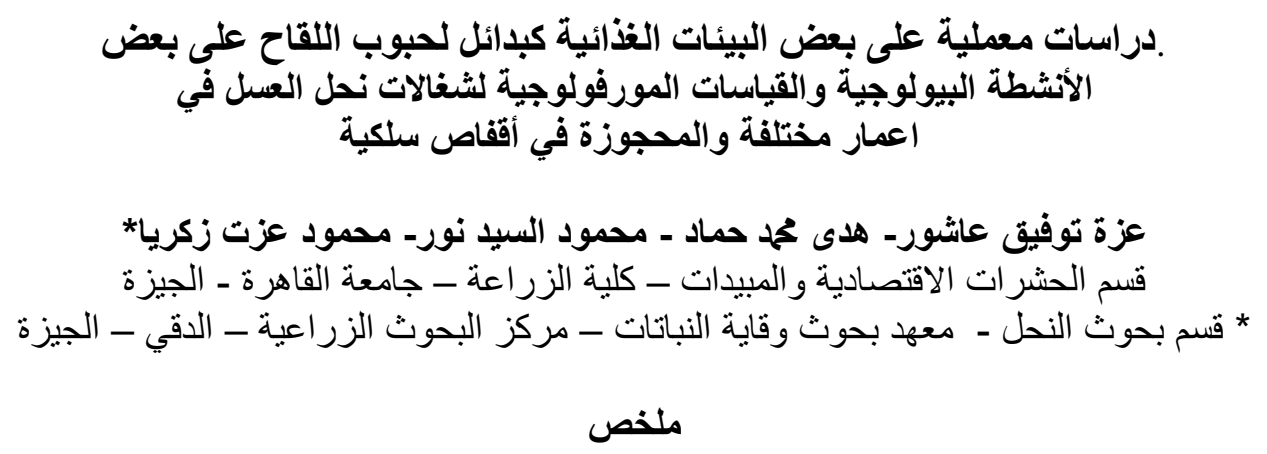

أجريت هذه الدر اسة لمعرفة تأثير البيئات الغذائية كبدائل لحبوب اللقاح على بعض الأنشطة البيولوجية والقياسات

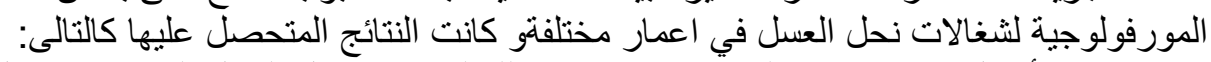



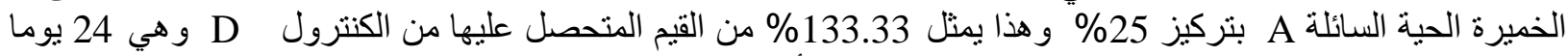

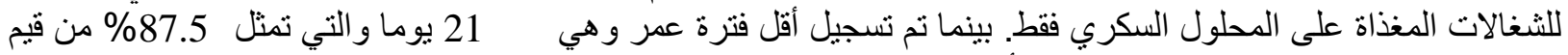

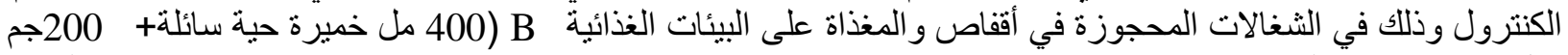

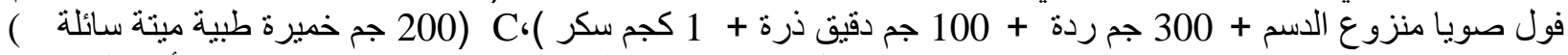
(كما كان تأثير الخميرة. Saccharomyces sp.)

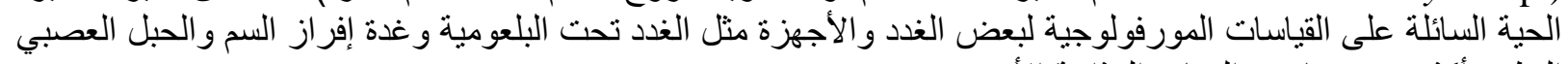

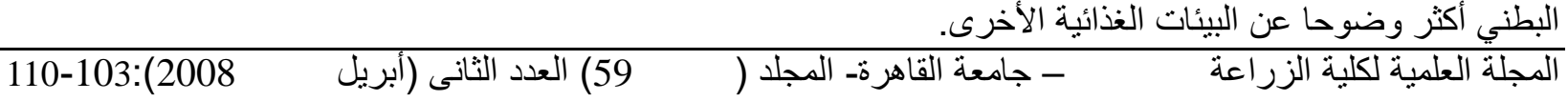


Laboratory studies of some diets as pollen ........................................................ 